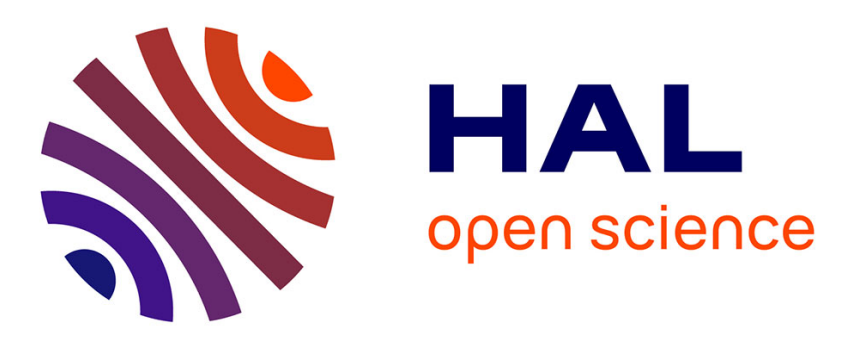

\title{
PREPARATION OF SEMICONDUCTING CERAMICS (NTC THERMISTORS) BY CHEMICAL METHOD
}

\author{
E. Jabry, G. Boissier, A. Rousset, R. Carnet, A. Lagrange
}

\section{To cite this version:}

E. Jabry, G. Boissier, A. Rousset, R. Carnet, A. Lagrange. PREPARATION OF SEMICONDUCTING CERAMICS (NTC THERMISTORS) BY CHEMICAL METHOD. Journal de Physique Colloques, 1986, 47 (C1), pp.C1-843-C1-847. 10.1051/jphyscol:19861129 . jpa-00225526

\section{HAL Id: jpa-00225526 https://hal.science/jpa-00225526}

Submitted on 1 Jan 1986

HAL is a multi-disciplinary open access archive for the deposit and dissemination of scientific research documents, whether they are published or not. The documents may come from teaching and research institutions in France or abroad, or from public or private research centers.
L'archive ouverte pluridisciplinaire HAL, est destinée au dépôt et à la diffusion de documents scientifiques de niveau recherche, publiés ou non, émanant des établissements d'enseignement et de recherche français ou étrangers, des laboratoires publics ou privés. 
JOURNAL DE PHYSIQUE

Colloque $\mathrm{Cl}$, supplément au $\mathrm{n}^{\circ} 2$, Tome 47, février 1986

page $\mathrm{C} 1-843$

\title{
PREPARATION OF SEMICONDUCTING CERAMICS (NTC THERMISTORS) BY CHEMICAL METHOD
}

\author{
E. JABRY, G. BOISSIER, A. ROUSSET, R. CARNET ${ }^{*}$ and A. LAGRANGE* \\ Laboratoire de Chimie des Matériaux Inorganiques, Université \\ Paul Sabatier, 118 Route de Narbonne, F-31062 Toulouse Cedex, \\ France \\ ${ }^{*}$ Société L.C.C.-C.I.C.E., (Groupe Thomson-CSF), Avenue du \\ Colonel prat, st Apollinnaire, F-21100 Dijon, France
}

\begin{abstract}
Rēsumé - La décomposition en atmosphère contrôlée de précurseurs oxaliques mixtes $\left(\mathrm{Mn}_{7-y^{N i}}\right) \mathrm{C}_{2} \mathrm{O}_{4}, 2 \mathrm{H}_{2} \mathrm{O}$ permet de preparer directement et à basse température $\left(600-700^{\circ} \mathrm{C}\right)$ des poudres de manganites de nickel $\mathrm{Mn}_{3-x^{N i}} \mathrm{x}_{4}(0<x<1)$ prēsentant une morphologie contrôlable. Ces poudres, frittées à $1160^{\circ} \mathrm{C}$ seulement, conduisent à des céramiques semi-conductrices très bien densifiées ( $96 \%$ de la densité théorique) et présentant des rësistivités êlectriques nettement plus faibles que celles observées jusque là pour de tels composēs.
\end{abstract}

Abstract - The decomposition in controlled atmosphere of mixed oxalic precursors (Mn $\left.1-\mathrm{Ni}_{y}\right) \mathrm{C}_{2} \mathrm{O}_{4}, 2 \mathrm{H}_{2} \mathrm{O}$ al lows at low temperature $\left(600-700^{\circ} \mathrm{C}\right)$, direct prept ration of powders of nickel manganites $\mathrm{Mn}_{3-x^{N i}} x_{4}{ }_{4}(0<x<1)$ producing a controlled morphology. These powders sintered at only $1160^{\circ} \mathrm{C}$ lead to highly densified semiconducting ceramics (96\% of the theoretical density) and have electrical resistivities clearly lower than those observed up until now for sych compounds.

\section{I - INTRODUCTION}

Thermistors with a Negative Temperature Coefficient (N.T.C.) are semiconducting ceramics, most often constituted by transition metals manganites. In these solids the electrical conductivity is due to the phenomenon of transfer of electrons (hopping) between the $\mathrm{Mn}^{3+}$ and $\mathrm{Mn}^{4+}$ ions in octahedral sites $/ 1 /$ The resistivity of these phases follows the classical law of semiconductors : $\rho=\rho_{0} e^{B / T}$ with $B=\frac{\Delta E}{2 K}, \Delta E$ is the activation energy of the hopping mechanism.

The necessity for improving the electrical properties of these electronic components necessitates the modification of the preparation process notably through the reaching of an optimized microstructure $/ 2 / / 3 /$. Therefor recent investigations have stressed the importance that must be given to the morphology of the powders submitted to sintering $/ 3 / / 4 / / 5 /$.

In this study we will reveal the interest of preparing powders of nickel manganites at low temperature which, as a result of this, have a controlled morphology. The sintering operation is then much simplified, it leads to very dense and well optimized ceramics as far as the electrical properties are concerned.

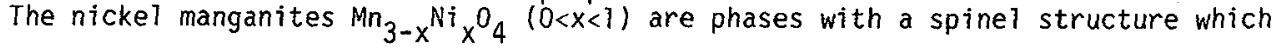
are very difficult to obtain in the pure state $/ 6 / / 7 / / 8 / 19 /$. Rather than using the conventional method of solid-solid reaction between $\mathrm{Mn}_{3} \mathrm{O}_{4}$ and $\mathrm{NiO}$ we have preferred 
to use the decomposition of a mixed organic precursor in order to obtain directly powders of nickel manganites. These powders may be sintered at relatively low temperatures wich appears as a great advantage as the nickel manganites are unstable at high temperature $/ 10 / / 11 \%$.

From a structural point of view, different distributions have been proposed in particular for the compound $\mathrm{NiMn}_{2} \mathrm{O}_{4}(x=1)$; we will adopt the model based on the stabilisation energies of the manganese and nickel ions in the crystalline field, namely $\mathrm{Mn}^{2+}\left|\mathrm{Mn}_{2-2 \mathrm{x}}^{3+} \mathrm{Mn}_{\mathrm{x}}^{4+} \mathrm{Ni}_{x}^{2+}\right| \mathrm{O}_{4}^{2-}(0<\mathrm{x}<1) / 12 /$.

II - PREPARATION OF NICKEL MANGANITES POWDERS

The powders result from the decomposition of oxalic precursors $\mathrm{Mn}_{1-y} \mathrm{Ni}_{y}\left(\mathrm{C}_{2} \mathrm{O}_{4}\right)_{2}$, $2 \mathrm{H}_{2} \mathrm{O} \quad(0<y<1 / 3)$ prepared by coprecipitation in aqueous solution. Different compositions have been studied as shown in table $I$ which also gives the compositions of the corresponding manganites $\mathrm{Mn}_{3-x} \mathrm{Ni}_{x} \mathrm{O}_{4}$ with $\mathrm{x}=3 y$ and $0<x<1$.

Table I

\begin{tabular}{|c|c|c|c|c|c|c|c|c|c|c|}
\hline$y$ & 0 & 0.025 & 0.100 & 0.155 & 0.195 & 0.220 & 0.235 & 0.270 & 0.285 & 0.325 \\
\hline$x$ & 0 & 0.07 & 0.30 & 0.47 & 0.58 & 0.66 & 0.71 & 0.81 & 0.85 & 0.97 \\
\hline
\end{tabular}

1. Decomposition of the mixed oxalates in air

Thermal decomposition processing is described elsewhere /13/. This process does not lead directly to the required spinel structure. In fact, beyond $420^{\circ} \mathrm{C}$, that is to say after the end of the decomposition, XRD analysis reveals a mixture of phases constituted of cubic $\mathrm{Mn}_{2} \mathrm{O}_{3}$ and of rhomboedral ferromagnetic $\mathrm{NiMnO}_{3}$.

Taking into account the high reactivity of the oxides, a thermal treatment of several hours at $800^{\circ} \mathrm{C}$ allows a simultaneous crystallisation of these oxides in an unique spinel phase according to the reaction

for all values $0,50<x<1$.

$$
x \mathrm{NiMnO}_{3}+(3 / 2-x) \mathrm{Mn}_{2} \mathrm{O}_{3}+\mathrm{Ni}_{x} \mathrm{Mn}_{3-\mathrm{x}_{4}} \mathrm{O}_{4}+1 / 4 \mathrm{O}_{2}
$$

Thus spinel phase is obtained at $800^{\circ} \mathrm{C}$ instead of at $1100^{\circ} \mathrm{C}$ with a conventional processing.

The morphologic analysis of the manganites thus prepared show that the powders are formed of rather strongly conglomerate particles with a large range of sizes

shapes and a low surface area $\left(1-2 \mathrm{~m}^{2} \mathrm{~g}^{-1}\right)$. Such characteristics which derived from the thermal treatment done during several hours at $800^{\circ} \mathrm{C}$, are not necessarily the best to optimize the microstructure in a further sintering operation. Better controlled properties would be hoped for in the case of these manganites if they were obtained directly at lower temperature. In this way it is essential to avoid the formation of the phase $\mathrm{Ni} \mathrm{Mn} \mathrm{O}_{3}$ in lowering the oxygen partial pressure during the precursor decomposition.

\section{Decomposition of the mixed oxalates in controlled atmosphere}

Due to the conventional atmosphere being too oxidizing, we have worked in mixtures of $\mathrm{N}_{2}+\mathrm{O}_{2}$, poorer in oxygen. After several tests, we have succeeded in obtaining directly and at low temperature $\left(000-700^{\circ} \mathrm{C}\right)$ monophasic manganites. The conditions we have used are the following :

a) Decomposition of the salt in a mixture of $\mathrm{N}_{2} / \mathrm{O}_{2}$ whose oxygen partial pressure is $7.510^{3}$ Pascal (Pa).

b) Heat treatment in neutral atmosphere from $420^{\circ} \mathrm{C}$ (soaking time : two hours) to $700^{\circ} \mathrm{C}$. c) Quenching

Pure phases have been obtained for the compounds $\mathrm{Mn}_{3-x} \mathrm{Ni}_{x} \mathrm{O}_{4}$ such that $x>0.50$ i.e.

for all the compounds concerning the N.T.C. thermistors. For high manganese contents 
it had been impossible, whatever the operating conditions, to end up with monophasic oxides. These results confirm those. of SARKAR $/ 9 /$ and WALCH $/ 10 /$ who admit a non miscibility of the oxides $\mathrm{Mn}_{3} \mathrm{O}_{4}$ and $\mathrm{NiO}$.

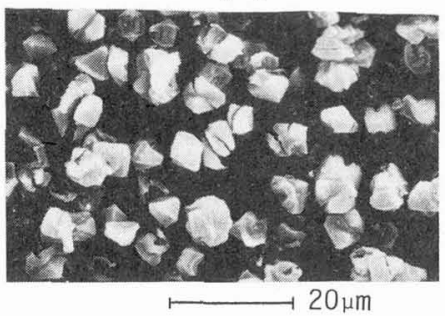

Fig. 1

The nickel manganites prepared in this way at relatively low temperature are constituted of very weakly agglomerated particles with a regular size and shape (small octahedra 4-5 $\mathrm{m}$ ) (figure $\mathrm{n}^{\circ} \mathrm{T}$ ). Their surface area evolves with the heat treatment and can be controlled before sintering.

\section{III - PREPARATION AND CHARACTERISATION OF THE CERAMICS}

\section{Preparation}

The powders formely obtained from 600 to $800^{\circ} \mathrm{C}$, either the ones prepared in air or especially the ones prepared incontrolled atmosphere, were put in a matrix after an organic binder had been added, applying a pressure of $4 \mathrm{~kb}$. The resulting discs, with a diameter $\emptyset=0.5 \mathrm{~cm}$ and thickness $\mathrm{e}=0.1 \mathrm{~cm}$, were submitted to different heat treatments in air with different profiles (table II).

\section{Characterisation}

Table II gives XRD anaTysis and densities.

\begin{tabular}{|c|c|c|c|c|c|c|c|c|}
\hline \multirow{3}{*}{$\frac{\mathrm{Mn}_{3-x^{N i} \mathrm{~N}_{4}}}{\text { composition }}$} & \multicolumn{4}{|c|}{ Sintering at $1160^{\circ} \mathrm{C}, 2 \mathrm{hrs}$, cooling at $30^{\circ} / \mathrm{hr}$} & \multicolumn{4}{|c|}{ Sintering at $1200^{\circ} \mathrm{C}$, 2hrs, cooling of $150^{\circ} \mathrm{C} / \mathrm{hr}$} \\
\hline & $\begin{array}{l}\text { Powder obta } \\
\text { atr } 800^{\circ} \mathrm{C}\end{array}$ & $\begin{array}{l}\text { ined in } \\
\text { ahrs }\end{array}$ & $\begin{array}{l}\text { Powder obte } \\
\mathrm{N}_{3} / 0_{2} \text { atmos }\end{array}$ & $\begin{array}{l}\text { ained in } \\
\text { sphere } 700^{\circ} \mathrm{C}\end{array}$ & $\begin{array}{l}\text { Powder obtain } \\
\text { air } 800^{\circ} \mathrm{C}\end{array}$ & $\begin{array}{l}\text { ined in } \\
\text { thr }\end{array}$ & $\begin{array}{l}\text { Powder obtai } \\
\mathrm{N}_{2} \mathrm{NO}_{2} \text { atmoss }\end{array}$ & $\begin{array}{l}\text { ained in } \\
\text { suhere } 700^{\circ} \mathrm{C}\end{array}$ \\
\hline & $\begin{array}{c}\text { Crystalline } \\
\text { phase }\end{array}$ & : Density & $\left\{\begin{array}{c}\text { Crystalline } \\
\text { phase }\end{array}\right.$ & Density & $\begin{array}{l}\text { Crystalline } \\
\text { phase }\end{array}$ & Denstty & $\begin{array}{l}\text { Crystalline: } \\
\text { phase }\end{array}$ & Density \\
\hline 0.58 & $\begin{array}{l}\text { cuble } \\
\text { spinel }\end{array}$ & 4.4. & $\begin{array}{l}\text { cubic } \\
\text { s.inel }\end{array}$ & $\begin{array}{l} \\
\vdots\end{array}$ & $\begin{array}{l}\text { cubic } \\
\text { sptnel }\end{array}$ & $\vdots 4.1$. & $\begin{array}{l}\text { cubic : } \\
\text { spinel : }\end{array}$ & 4.7 \\
\hline 0.66 & $\begin{array}{l}\text { cubic } \\
\text { spinel }\end{array}$ & 4.4 & $\begin{array}{l}\text { cubic } \\
\text { spinel }\end{array}$ & 4.8 & $\begin{array}{l}\text { cubic } \\
\text { spinel }\end{array}$ & 4.2 & $\begin{array}{l}\text { cubic : } \\
\text { spinel : }\end{array}$ & 4.8 \\
\hline 0.71 & $\begin{array}{l}\text { cubic } \\
\text { spinel }\end{array}$ & 4.4. & $\begin{array}{l}\text { cuble } \\
\text { spinel }\end{array}$ & : 4.8 & $\begin{array}{l}\text { cubfic } \\
\text { spinel }\end{array}$ & 4.2 & $\begin{array}{l}\text { Cubic : } \\
\text { spinel : }\end{array}$ & $\vdots$ \\
\hline 0.81 & $\begin{array}{l}\text { cubic } \\
\text { spinel }\end{array}$ & $\begin{array}{ll}\vdots & 4.5 \\
\vdots & \\
\end{array}$ & $\begin{array}{l}\text { cubic } \\
\text { spinel }\end{array}$ & $\vdots: 9.9$ & $\begin{array}{l}\text { cubic } \\
\text { spinel }\end{array}$ & 4.4 & $\begin{array}{l}\text { cubic } \\
\text { spinel }\end{array}$ & $\vdots$ \\
\hline 0.85 & $\begin{array}{l}\text { cubic } \\
\text { spinel }\end{array}$ & $\begin{array}{ll}\vdots & \\
\vdots & 4.5 \\
\end{array}$ & $\begin{array}{l}\text { cubic } \\
\text { spinel }\end{array}$ & $: 4.9$ & $\begin{array}{l}\text { cubic } \\
\text { spinel }\end{array}$ & 4.4 & $\begin{array}{l}\text { cuoic } \\
\text { spinel }\end{array}$ & $\vdots$ \\
\hline 0.97 & $\begin{array}{l}\text { cubic } \\
\text { spine] }\end{array}$ & $\begin{array}{l}\vdots \\
\vdots\end{array}$ & $\begin{array}{l}\text { cublc } \\
\text { spinel } \\
+ \text { Nito } \\
\end{array}$ & $\begin{array}{l}\vdots .9 \\
\vdots \\
\end{array}$ & $\begin{array}{l}\text { cubic } \\
\text { spine? } \\
+\quad \text { Nito } \\
\end{array}$ & $\vdots 4.5$ & $\begin{array}{l}\text { cubic : } \\
\text { spinel : }\end{array}$ & $\vdots$ \\
\hline
\end{tabular}

Table II

Diffraction analysis revealed the presence of spinel structure and the absence of any other crystalline compounds $\left(\mathrm{NiO}+\mathrm{Mn}_{3} \mathrm{O}_{4}\right)$. The ceramics prepared from powders obtained in controlled atmosphere have a higher density than those treated in air atmosphere (figure 2). High densities are obtained for relatively low sintering temperature $\left(1160^{\circ} \mathrm{C}\right)$. The grain size is about $20 \mu \mathrm{m}$. Finally, it is necessary to point out that the sintering of the powders $\mathrm{Mn}_{3} \mathrm{O}_{4}$ and $\mathrm{NiO}$ heat treated in the same conditions $\left(1160^{\circ} \mathrm{C}\right)$ lead to incomplete solide-solid reactions and that the densities remain low, about 4.2. $\mathrm{g} \cdot \mathrm{cm}^{-3}$.

The figures $n^{\circ} 3$ and 4 allows us to define the differences of microstructure observed. Figure $n^{\circ} 4$ shows a more heterogeneous grains size and an important porosity. 


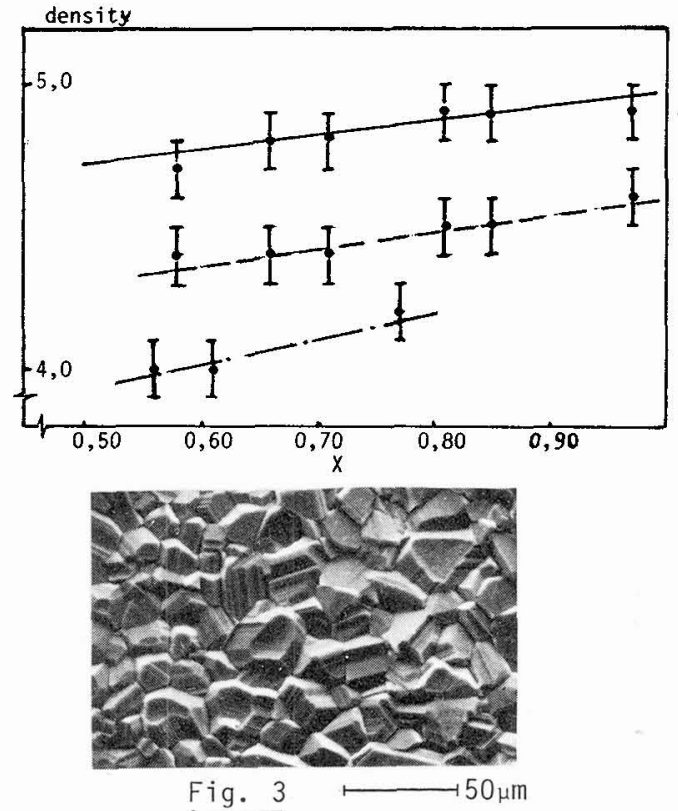

Fig.2: Change of density with the nickel content Sintering at $1160^{\circ} \mathrm{C}, 2 \mathrm{H}, \mathrm{cooling}$ at $30^{\circ} \mathrm{C} / \mathrm{h}$ starting powders obtained at $700^{\circ} \mathrm{C}$ in controlled atmosphere, $7,510^{3}$ Pascal ( $\mathrm{Pa}$ ). starting powders obtained at $800^{\circ} \mathrm{C}$

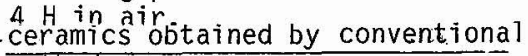
method

Tsintering at $1200^{\circ} \mathrm{C}, 2 \mathrm{H}$ )

IV - ELECTRICAL PROPERTIES OF THE N.T.C. THERMISTORS

To determine the electric characteristics, the samples were electroded with silver print and fired at $800^{\circ} \mathrm{C}$. The resistivity is determined by resistance measurements at $25 \pm 0.05^{\circ} \mathrm{C}$ and using the relationship $\rho=\frac{R S}{e}(R=$ resistance in ohms, $S=$ surface in $\mathrm{cm}^{2}$, $\mathrm{e}=$ thickness in $\mathrm{cm}$ ). A second measurement done at $85 \pm 0.05^{\circ} \mathrm{C}$ allows deduction of the thermal sensitivity coefficient B $/ 1 /$.

The results obtained are shown in figure 5 .

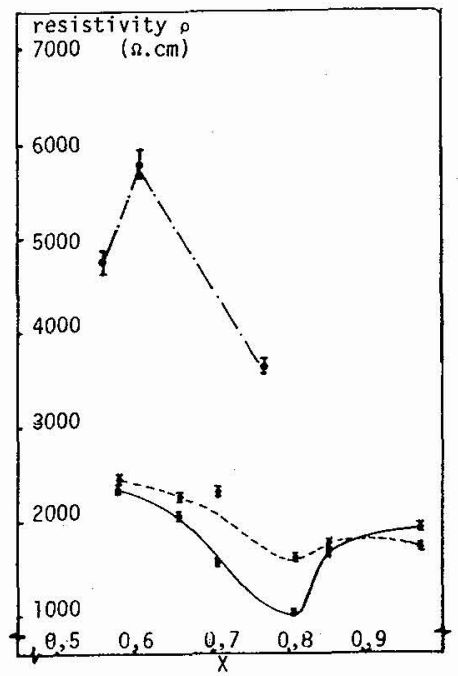

Fig. 5 : Change of resistivity with the nickel content.

Sintering at $1160^{\circ} \mathrm{C}, 2 \mathrm{H}$ cooling at $30^{\circ} \mathrm{C} / \mathrm{h}$

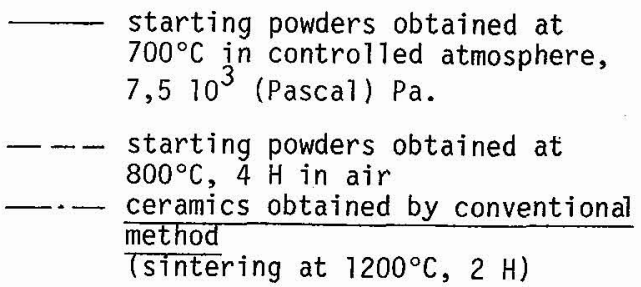


For similar sintering and composition, we can observe sensible divergences of resistivity which can be attribued to the differences of microstructure. Ceramics with the higher densities exhibit lower resistivities. The minimum resistivity $(1030 \Omega . \mathrm{cm})$ is the lowest of all the ones we have found in the bibliography concerning the nickel manganites. It means that the electrical properties of these compounds were not optimized and that it is probably still possible to obtain inferior values by increasing the densification.

The sintering temperatures above $1160^{\circ} \mathrm{C}$ did not allow improvement in the electrical performances from the powders produced by chemical methods.

on the other hand, for the ceramics prepared from solid-solid reactions between $\mathrm{Mn}_{3} \mathrm{O}_{4}$ and $\mathrm{Ni0}$, the best results are observed at a sintering temperature of $1300^{\circ} \mathrm{C}$, which allows a minimum of resistivity at $2200 \Omega . \mathrm{cm}$ only.

Figure 2 shows the resistivity versus nickel content. For the ceramics obtained by conventional method and sintered at $1200^{\circ} \mathrm{C}$, i.e. in conditions rather close to those prepared by chemical method, we observe high values of resistivity as wellas very irregular variations with the nickel content, which shows little coherence with the model proposed. Such characteristics can be explained by considering that the substitution of nickel in the spinel lattice is not controlled as confirmed by the XRD studies

On the other hand, whatever the sintering temperature, the ceramics prepared by che mical method show a minimum of resistivity. This appears for a nickel content of $x=0.80$ whereas theoretically this minimum was expected for $x=0.66$. This divergence can be the result of a distribution slightly different from the one proposed initially, taking into account the presence of $\mathrm{Ni}^{2+}$ ions in the tetrahedral sites for example and in the case of the compound $\mathrm{NiMn}_{2} \mathrm{O}_{4}$ it has already been proposed
$/ 11 / / 14 \%$.

$V-$ CONCLUSION

The preparation by chemical process at relatively low temperature of pure powders of nickel manganites with a controlled morphology has a benificial effect on the density of N.T.C. ceramics. Besides lower sintering temperature, clearly lower resistivites can be obtained and a better correlation of the electrical properties with the nickel content can be observed In contrast to the conventional process based on the reaction at high temperature of mixture of manganese and nickel oxides, this method allows us to break away from the problems of purity but also from problems of morphology of raw materials, which through the microstructure largely influences the electrical properties. In this way using chemical process makes the optimisation of electrical properties of nickel based manganites easier.

\section{REFERENCES}

1/ Macklen, E.D., Thermistors Electrochemical Publication (1979).

12/ Yan, F.,Mat. Science and Engineering 48 (1981) 53.

$13 /$ Boissier, G., Thèse 3ème cycle Toulouse (1984).

14/ Kingery, W. and Uh7mann, D.R., John Wiley and Sons Inc. New York (7975).

15/ Haussonne, J.M., Rev. Int. Hautes Temper. Refreact. 21 (1984) 95.

/6/ Villers, G. and Buhl, R., C.R. Acad. Sci. Paris t 260 (1965) 3406.

17/ Baffier, N. and Huber, M. , J. Phys. Chem. Solids 33 (1972) 737.

/8/ Boucher, B., Buhl, R. and Perrin, M., Acta Cryst. B25 (1969) 2326.

19/ Sarkar, S.K., Sharma, M.L., Bhaskar, H.L. and NagpaT, K.C., J. of Mat. Science 19 (1984) 545.

/10/ Walch, H., Siemens Leitschuft $47 n^{\circ} 1$ (1973) 65.

/1T/ Larson, E.G. Arnott, R.J. and Wickham, D.G., J. Phys. Chem. Solids 23 (1962)1771. /12/ Dunitz, J.D. and Orgel, L.E., J. Phys. Chem. Solids 3 (1957) 20.

/13/ Jabry, E., Thèse Doctorat I.N.P. de Toulouse (1985).

/14/ Brabers, V.A.M. and Terhel1, J.C.J.M., Phys. Stat. Sol. (a) 69 (1982) 325. 